\title{
$\begin{array}{ll}\text { Research Square } & \begin{array}{l}\text { Preprints are preliminary reports that have not undergone peer review. } \\ \text { They should not be considered conclusive, used to inform clinical practice, } \\ \text { or referenced by the media as validated information. }\end{array}\end{array}$
}

\section{Inheritance of growth habit under photoperiod insensitive genetic background in dolichos bean (Lablab purpureus (L.) Sweet)}

Gonal Basanagouda ( $\sim$ basanagoudagonal@gmail.com )

University of Agricultural Sciences https://orcid.org/0000-0003-1750-6641

Sampangi Ramesh

University of Agricultural Sciences https://orcid.org/0000-0001-9666-7974

Basalapura Rangegowda Chandana

University of Agricultural Sciences

Chindi Basavaraj Siddu

University of Agricultural Sciences

\section{Rotti Kirankumar}

University of Agricultural Sciences

\section{Mugali Pundalik Kalpana}

University of Agricultural Sciences

\section{Research Article}

Keywords: Determinate, Growth habit, ndeterminate, Inheritance, Photoperiod sensitivity

Posted Date: November 15th, 2021

DOI: https://doi.org/10.21203/rs.3.rs-1050448/v1

License: (9) This work is licensed under a Creative Commons Attribution 4.0 International License. Read Full License 


\section{Abstract}

Development of high yielding cultivars with determinate growth habit in photoperiod insensitive (PIS) background is one of the major objectives of breeding grain legumes crops including dolichos bean. A thoroughly validated genetic basis is a prerequisite for breeding dolichos bean for determinate growth habit in PIS background. Based on the published reports by researchers of our laboratory and those by others, and our unpublished data, we hypothesized that the number and mode of action of genes controlling growth habit differ with degree of photoperiod sensitivity of the genetic material used to investigate the inheritance of growth habit in dolichos bean. To test this hypothesis, we compared the number and mode of action of genes controlling growth habit between segregating generations in Photoperiod sensitive (PS) and those in PIS genetic backgrounds. While indeterminate and determinate plants segregated in 15:1 ratio in $F_{2}$ populations derived from crosses between determinate PIS and indeterminate PIS parents, they segregated in 9:7 ratio with indeterminacy being dominant in $F_{2}$ populations derived from crosses between determinate PIS and indeterminate PS parents. These patterns of segregation (15:1 and 9:7) in favour of indeterminate and determinate plants, respectively in $F_{2}$ populations were confirmed in $F_{3}$ populations of PIS and PS genetic backgrounds based on good fit between observed and expected ratios (55:9 and 29:35, respectively) in favour of indeterminate and determinate plants, respectively. The patterns of segregation in $F_{2}$ populations were further confirmed in $\mathrm{F}_{3}$ populations based on good fit between observed and expected ratios of 3:1 segregating and non-segregating families, and of 3:1 indeterminate and determinate non-segregating families, respectively.

\section{Introduction}

Dolichos bean or Hyacinth bean or Indian bean is one of the oldest legume cropsgrown in dry and semi-arid regions of Asia, Africa and America (Ramesh and Byregowda 2016). It is a multi-utility legume crop grown for vegetable, pulse, fodder and green manure purposes (Ramesh and Byregowda 2016). After maturity, dry seeds are harvested and stored, and consumed as whole grains or as split dhal throughout the year. In India, it is extensively grown in southern states. It is one of the major sources of dietary protein to millions of people who depend primarily on vegetarian source of energy. It is grown either in pure crop or intercropped with cereals like finger millet, pearl millet, corn and sorghumin rainfed ecosystems (Keerthi et al. 2016).

Dolichos bean has evolved as photoperiod sensitive (PS) crop and exhibits determinate and indeterminate types of growth habit (Keerthi et al. 2018; Vinita et al. 2019; Supriya et al. 2019). It requires short-days for transition from vegetative to reproductive stage (Kim and Okubo 1995; Kim and Okubo 1996; Keerthi et al. 2014, 2016, 2018). Most of the naturally occurring dolichos bean genotypes are indeterminate and PS. However, a few naturally occurring photoperiod insensitive (PIS) determinate genotypes have been identified (Ramesh and Byregowda 2016). Thus, determinate growth habit and photoperiod insensitivity in dolichos bean like in other grain legumes are considered as domestication syndrome traits (Huyghe 1998). In indeterminate plants, main stem continues to grow under favourable conditions, and only primary and secondary branches terminate in inflorescence only under short-days (Harland 1920; Kim and Okubo 1995; Sultana et al. 2001; Keerthi et al. 2018). Majority of traditional cultivars exhibit indeterminate growth habit and are highly PS and requires short days for flowering (Sultana et al. 2001; Keerthi et al. 2018). Indeterminate cultivars exhibit delayed flowering under long-days and the extent of delay is a function of day-length. These features of indeterminate cultivars restrict their adaptation to production environments with short day-length. Asynchronous flowering, and pod development and maturity driven by long overlapping vegetative and reproductive phases (among others) are attributed to poor partitioning of photosynthates and hence low harvest index of cultivars with indeterminate growth habit (Huyghe 1998). In determinate plants, the main stem, and primary and secondary branches terminate in inflorescence (Harland 1920; Kim and Okubo 1995; Sultana et al. 2001; Keerthi et al. 2018). Determinate plants require constant number of days for transition from vegetative to reproductive stage irrespective of day length (Harland 1920; Kim and Okubo 1995; Kim and Okubo 1996; Sultana et al. 2001; Keerthi et al. 2014, 2016, 2018). Greater synchronous flowering, pod development and maturity driven by shorter overlapping vegetative and reproductive phases contribute to greater harvest index of cultivars with determinate growth 
habit (Keerthi et al. 2018; Kaushal et al. 2019; Kato et al. 2019; Supriya et al. 2021). The compact growth habit of determinate genotypes facilitates high density planting that help maximize productivity (Kim et al. 1992; Keerthi et al. 2018). These features of determinate genotypes along with short crop growth and maturity period make them most ideal cultivar

types suitable for mechanical harvesting and for multiple and intercropping production systems. Thus, determinate cultivars in dolichos bean are gaining increased popularity among the farmers. A precise knowledge on genetic basis of growth habit would provide useful clues (among others) for adopting the most appropriate selection and breeding strategies for developing determinate cultivars.

The reported literature indicates varying number and mode of action of genes controlling inheritance of growth habit in dolichos bean. While researchers of our laboratory have reported both di-genic (Keerthi et al. 2016) and tri-genic (Keerthi et al. 2014) complementary epistatic control, Kaushal et al. (2019) have reported monogenic control of inheritance of growth habit in dolichos bean. All these researchers have reported dominance of indeterminacy. Given that alleles controlling determinate growth habit and photoperiod insensitivity, and those controlling indeterminate growth habit and photoperiod sensitivity are tightly linked (with a recombination of 0.20 to 0.26 ) in coupling phase (Keerthi et al. 2014, 2016; Kaushal et al. 2019), the reported number and mode of action of genes controlling the inheritance of growth habit in dolichos bean are based on segregating generations derived from crosses between parents with determinate growth habit in PIS background and those with indeterminate growth habit in PS background. With an objective of breeding cultivars with determinate growth habit in PIS background, we identified a few indeterminate PIS advance breeding lines (ABLs). We generated segregating populations derived from crosses between these indeterminate PIS ABLs and determinate PIS parents. To our surprise, we recovered far lower frequency (6.25\%) of determinate plants than expected based on either mono-genic inheritance (3 indeterminate: 1 determinate) (25\%) (Kaushal et al. 2019) or di-genic epistatic inheritance (9 indeterminate: 7 determinate) (44\%) (Keerthi et al. 2016) or tri-genic epistatic inheritance (57 indeterminate: 7 determinate) (11\%) (Keerthi et al. 2014) of growth habit in dolichos bean. These observations, contrary to our expectation, prompted us to hypothesize that the number and mode of action of genes controlling inheritance of growth habit in dolichos bean are likely to differ with the degree of photoperiod sensitivity of genetic material used for the study. To test this hypothesis, the present study was conducted with an objective to compare the number and mode of action of genes controlling growth habit between PS and PIS genetic backgrounds in dolichos bean.

\section{Material And Methods}

The basic material consisted of two PIS indeterminate genotypes (HA 5 and GL 201), one PIS determinate genotype (HA 4) and one PS indeterminate genotype (GL 66) (Table 1). The seeds of these four genotypes were space planted in crossing block located at the experimental plot of the Department of Genetics and Plant Breeding (GPB), College of Agriculture (CoA), University of Agricultural Sciences (UAS), Bangalore, India during 2020 rainy season. Five healthy plants of each of these four parents were maintained.

Table 1 Growth habit, photoperiod sensitivity and pedigree/source of parents used to derive crosses in dolichos bean 


\begin{tabular}{|c|c|c|c|c|c|}
\hline Parents & Growth Habit & $\begin{array}{l}\text { Photoperiod } \\
\text { sensitivity }\end{array}$ & Source & $\begin{array}{l}\text { Pedigree/ } \\
\text { Source }\end{array}$ & Reference \\
\hline HA 4 & Determinate & Insensitive & $\begin{array}{l}\text { Karnataka, } \\
\text { India }\end{array}$ & $\begin{array}{l}\text { HA } 3 \times \text { Magadi } \\
\text { local }\end{array}$ & $\begin{array}{l}\text { Ramesh and Byregowda } \\
(2016)\end{array}$ \\
\hline HA 5 & Indeterminate & Insensitive & $\begin{array}{l}\text { Karnataka, } \\
\text { India }\end{array}$ & $\mathrm{HA} 4 \times \mathrm{GL} 153$ & Ramesh et al. (2018) \\
\hline GL 66 & Indeterminate & Sensitive & $\begin{array}{l}\text { Karnataka, } \\
\text { India }\end{array}$ & $\begin{array}{l}\text { Germplasm } \\
\text { accession }\end{array}$ & Laxmi et al. (2016) \\
\hline GL 201 & Indeterminate & Insensitive & $\begin{array}{l}\text { Karnataka, } \\
\text { India }\end{array}$ & $\begin{array}{l}\text { Germplasm } \\
\text { accession }\end{array}$ & Laxmi et al. (2016) \\
\hline
\end{tabular}

\section{Development and characterization of experimental material for growth habit}

Involving three PIS parents, four crosses which included two straight ones (HA $4 \times$ HA 5 and HA $4 \times$ GL 201) and their two reciprocals (HA $5 \times$ HA 4 and GL $201 \times 1$ HA 4) were affected. Another cross (HA $4 \times$ GL 66) involving PIS determinate and PS indeterminate parents was also affected. The four crosses in PIS background and one cross in PS background constituted the experimental material. For affecting the crosses, the flowers were emasculated in designated female parents, the evening of the day before pollination on next day morning. The emasculated flowers were pollinated using the pollen grains collected from designated male parents of afore-mentioned five planned crosses (HA $4 \times$ HA 5, HA $5 \times$ HA 4 , HA $4 \times$ GL 201, GL $201 \times$ HA 4 and HA $4 \times$ GL66) during 2020 rainy season. A total of 15, 14, 12, 13, 8 well-filled $F_{1}$ seeds could be obtained from HA $4 \times$ HA 5, HA $5 \times$ HA 4, HA $4 \times$ GL 201, GL $201 \times$ HA 4 and HA $4 \times$ GL 66 crosses, respectively. The seeds of four parents and $F_{1}$ 's were space-planted during 2020 postrainy season. The seeds of the four parents and all the $F_{1}$ seeds germinated and survived to maturity. A total of 10 plants from each of the four parents and all the $F_{1}$ plants that survived were maintained. The selfed pods from $F_{1}$ 's of the five crosses were harvested, hand-threshed and sun-dried to obtain $F_{2}$ seeds. The $F_{2}$ seeds from these five crosses were space-planted during 2021 summer season. A total of 236, 225, 249, 216 and $215 \mathrm{~F}_{2}$ plants of HA $4 \times$ HA 5, HA $5 \times$ HA 4, HA $4 \times$ GL 201, GL $201 \times$ HA 4 and HA $4 \times$ GL 66 crosses, respectively survived to maturity. Selfed pods from each $\mathrm{F}_{2}$ plants were manually harvested, hand-threshed and seeds were sun-dried for use in raising $F_{3}$ population during 2021 rainy season. The seeds of each $F_{2}$ plants of the five crosses were planted in two rows of $3 \mathrm{~m}$ length spaced $0.60 \mathrm{~m}$ apart. A total of 949 plants in HA $4 \times$ HA 5, 921 in HA $5 \times$ HA 4,345 in HA 4 $\times$ GL201, 337 in GL $201 \times$ HA 4 and 955 plants in HA 4 × GL 66 survived to maturity in $\mathrm{F}_{3}$ generation. The recommended production and protection practices were followed to raise healthy plants in parents, $F_{1}, F_{2}$ and $F_{3}$ generations of the five crosses.

\section{Data recording and statistical analysis}

Each plant of the parents, $F_{1}, F_{2}$ and $F_{3}$ plants of the five crosses were inspected and their growth habit was recorded at maximum pod formation stage. The $F_{1}$ 's of all the five crosses displayed indeterminate growth habit. Two distinct growth habits could be observed in $\mathrm{F}_{2}$ and $\mathrm{F}_{3}$ generations of both crosses. All the plants with continuously growing main stem and bearing inflorescence only in primary and secondary branches similar to those in indeterminate parents were classified as indeterminate (ID); and plants with main stem terminating in inflorescence and bearing inflorescence even in primary and secondary branches similar to those in determinate parents as determinate (D) (Keerthi et al. 2014, 2016; Kaushal et al. 2019). The number of plants displaying determinate and indeterminate growth habits was counted. Based on hypothesized inheritance pattern, goodness of fit between observed and expected segregation ratio of 15 indeterminate: 1 determinate plants in $F_{2}$ generations and 55 indeterminate: 9 determinate plants in $F_{3}$ generations of the four crosses involving parents differing in growth habit under PIS background were examined using chi-square test. Similarly, goodness of fit between 
observed and expected segregation ratio of 9 indeterminate: 7 determinate plants in $\mathrm{F}_{2}$ generations and 25 indeterminate: 39 determinate plants in $\mathrm{F}_{3}$ generations of the cross involving parents differing in growth habit under PS background were also examined using chi-square test. Further, to conform observed pattern of segregation in $\mathrm{F}_{2}$ generations, the goodness of fit between observed and expected ratio of 3 segregating: 1 non-segregating $F_{3}$ families for growth habit, and expected ratio of 3 indeterminate: 1 determinate non-segregating $F_{3}$ families were examined using chi-square test. The All the analyses were implemented using "data analysis" option of Microsoft Excel software. Non-significance of chi-square tests was considered as an evidence for di-genic duplicate dominance and complementary epistatic genetic control of growth habit and dominance of indeterminacy over determinacy in four crosses under PIS and one cross in PS backgrounds, respectively.

\section{Results}

The $F_{1}$ 's of all crosses exhibited indeterminate growth habit suggesting dominance of indeterminacy. Appearance of both determinate and indeterminate plants with a greater frequency of the former in $\mathrm{F}_{2}$ generations derived from all the five crosses not only confirmed that the $F_{1}$ 's were true crosses but also confirmed the dominance of indeterminacy. Further, a greater frequency of indeterminate plants and a good fit of observed numbers of indeterminate and determinate plants to those expected based on hypothetical segregation ratio of 9 indeterminate: 7 determinate plants in $\mathrm{F}_{2}$ generation suggested that growth habit is controlled by two genes that display classical complementary epistasis in crosses involving PS parents (Table 2). Digenic complementary epistatic control of growth habit was confirmed in $F_{3}$ generation based on goodness of fit between observed and expected segregation ratio of 25 indeterminate: 39 determinate $F_{3}$ plants from crosses involving PS parents (Table 3). However, $F_{2}$ plants segregated in expected segregation of 15 indeterminate: 1 determinate ratio suggesting that growth habit is controlled by two genes that display duplicate dominance epistasis in crosses derived from PIS parents (Table 2). These results were confirmed in $\mathrm{F}_{3}$ generation where, the plants segregated in expected 55 determinate: 9 determinate ratio in crosses derived from PIS parents, as indicated by non-significant chi-square test (Table 3). In all the five crosses, irrespective of photoperiod sensitivity of parents, there existed good agreement between observed and expected number of 3 segregating: 1 non-segregating $F_{3}$ families (Table 4), and between observed and expected number of non-segregating 3 indeterminate: 1 determinate $F_{3}$ families (Table 5).

Table 2

The observed pattern of segregation for growth habit and its goodness of fit to that expected in

\begin{tabular}{|llllll|}
\hline Parents & Growth Habit & $\begin{array}{l}\text { Photoperiod } \\
\text { sensitivity }\end{array}$ & Source & Pedigree/ & Source \\
\hline HA 4 & Determinate & Insensitive & $\begin{array}{l}\text { Karnataka, } \\
\text { India }\end{array}$ & $\begin{array}{l}\text { HA 3 } \times \text { Magadi } \\
\text { local }\end{array}$ & $\begin{array}{l}\text { Ramesh and Byregowda } \\
(2016)\end{array}$ \\
\hline HA 5 & Indeterminate & Insensitive & $\begin{array}{l}\text { Karnataka, } \\
\text { India }\end{array}$ & HA 4 × GL 153 & Ramesh et al. (2018) \\
\hline GL 66 & Indeterminate & Sensitive & $\begin{array}{l}\text { Karnataka, } \\
\text { India }\end{array}$ & $\begin{array}{l}\text { Germplasm } \\
\text { accession }\end{array}$ & Laxmi et al. (2016) \\
\hline GL 201 & Indeterminate & Insensitive & $\begin{array}{l}\text { Karnataka, } \\
\text { India }\end{array}$ & $\begin{array}{l}\text { Germplasm } \\
\text { accession }\end{array}$ & Laxmi et al. (2016) \\
\hline $\begin{array}{l}\mathbf{F}_{2} \text { generations derived from four crosses in photo-period insensitive and one cross in photo-period sensitive genetic } \\
\text { backgrounds in dolichos bean }\end{array}$ & & & \\
\hline
\end{tabular}


Table 3

The observed pattern of segregation for growth habit and its goodness of fit to that expected in

\begin{tabular}{|c|c|c|c|c|c|c|c|}
\hline \multirow[t]{2}{*}{ Crosses } & \multicolumn{2}{|c|}{$\begin{array}{l}\text { Observed number of } F_{2} \\
\text { plants }\end{array}$} & \multirow[t]{2}{*}{$\begin{array}{l}\text { Hypothesized } \\
\text { ratio of ID } \\
\text { and D plants }\end{array}$} & \multicolumn{2}{|c|}{$\begin{array}{l}\text { Expected number of } F_{2} \\
\text { plants based on } \\
\text { hypothesized ratio of } 15 \text { ID: } 1 \\
D\end{array}$} & \multirow[t]{2}{*}{$\begin{array}{l}\text { Chi } \\
\text { square } \\
\text { statistic }\end{array}$} & \multirow[t]{2}{*}{ Probability } \\
\hline & $\begin{array}{l}\text { Indeterminate } \\
\text { (ID) }\end{array}$ & $\begin{array}{l}\text { Determinate } \\
\text { (D) }\end{array}$ & & $\begin{array}{l}\text { Indeterminate } \\
\text { (ID) }\end{array}$ & $\begin{array}{l}\text { Determinate } \\
\text { (D) }\end{array}$ & & \\
\hline \multicolumn{8}{|l|}{$\begin{array}{l}\text { Photo- } \\
\text { period } \\
\text { insensitive } \\
\text { background }\end{array}$} \\
\hline $\begin{array}{l}\mathrm{HA} \\
5\end{array}$ & 218 & 18 & $15 \mathrm{ID}: 1 \mathrm{D}$ & 221.25 & 14.75 & 0.76 & 0.38 \\
\hline $\begin{array}{l}\mathrm{HA} 5 \times \mathrm{HA} \\
4\end{array}$ & 209 & 16 & $15 \mathrm{ID}: 1 \mathrm{D}$ & 210.94 & 14.06 & 0.59 & 0.29 \\
\hline $\begin{array}{l}\mathrm{HA} 4 \times \mathrm{GL} \\
201\end{array}$ & 230 & 19 & 15 ID : $1 \mathrm{D}$ & 233.44 & 15.56 & 0.81 & 0.37 \\
\hline $\begin{array}{l}\text { GL } 201 \times \\
\text { HA } 4\end{array}$ & 202 & 14 & $15 \mathrm{ID}: 1 \mathrm{D}$ & 202.50 & 13.50 & 0.02 & 0.89 \\
\hline Pooled & 859 & 67 & 15 ID : $1 \mathrm{D}$ & 868.10 & 57.90 & 1.53 & 0.21 \\
\hline \multicolumn{8}{|l|}{$\begin{array}{l}\text { Photo- } \\
\text { period } \\
\text { sensitive } \\
\text { background }\end{array}$} \\
\hline $\begin{array}{l}\mathrm{HA} 4 \times \mathrm{GL} \\
66\end{array}$ & 124 & 91 & 9 ID : 7 D & 120.94 & 94.06 & 0.18 & 0.68 \\
\hline $\begin{array}{l}F_{3} \text { generati } \\
\text { backgrounc }\end{array}$ & $\begin{array}{l}\text { derived from fo } \\
\text { dolichos bean }\end{array}$ & crosses in p & o-period inse & tive and one cro & in photo-pe & d sensitiv & genetic \\
\hline
\end{tabular}


Table 4

The observed numbers of $\mathrm{F}_{3}$ families non-segregating and segregating for determinacy and indeterminacy and their goodness of fit to those expected in four crosses in photo-period insensitive and one cross in photo-period sensitive genetic backgrounds in dolichos bean

\begin{tabular}{|c|c|c|c|c|c|c|c|}
\hline \multirow[t]{2}{*}{ Crosses } & \multicolumn{2}{|c|}{$\begin{array}{l}\text { Observed number of } \mathrm{F}_{3} \\
\text { plants }\end{array}$} & \multirow[t]{2}{*}{$\begin{array}{l}\text { Hypothesized } \\
\text { ratio of ID } \\
\text { and D plants }\end{array}$} & \multicolumn{2}{|c|}{$\begin{array}{l}\text { Expected number of } F_{3} \\
\text { plants based on } \\
\text { hypothesized ratio of } 55 \text { ID: } 9 \\
\text { D }\end{array}$} & \multirow[t]{2}{*}{$\begin{array}{l}\text { Chi } \\
\text { square } \\
\text { statistic }\end{array}$} & \multirow[t]{2}{*}{ Probability } \\
\hline & $\begin{array}{l}\text { Indeterminate } \\
\text { (ID) }\end{array}$ & $\begin{array}{l}\text { Determinate } \\
\text { (D) }\end{array}$ & & $\begin{array}{l}\text { Indeterminate } \\
\text { (ID) }\end{array}$ & $\begin{array}{l}\text { Determinate } \\
\text { (D) }\end{array}$ & & \\
\hline \multicolumn{8}{|c|}{$\begin{array}{l}\text { Photo- } \\
\text { period } \\
\text { insensitive } \\
\text { background }\end{array}$} \\
\hline $\begin{array}{l}\mathrm{HA}_{5} 4 \times \mathrm{HA} \\
\end{array}$ & 830 & 119 & $55 \mathrm{ID}: 9 \mathrm{D}$ & 815.55 & 133.45 & 1.82 & 0.18 \\
\hline${ }_{4}^{\mathrm{HA}} 5 \times \mathrm{HA}$ & 810 & 111 & $55 \mathrm{ID}: 9 \mathrm{D}$ & 791.50 & 129.50 & 3.07 & 0.08 \\
\hline $\begin{array}{l}\mathrm{HA} 4 \times \mathrm{GL} \\
201\end{array}$ & 295 & 50 & $55 \mathrm{ID}: 9 \mathrm{D}$ & 296.50 & 48.50 & 0.05 & 0.82 \\
\hline $\begin{array}{l}\text { GL } 201 \times \\
\text { HA } 4\end{array}$ & 289 & 48 & 55 ID :9 D & 289.60 & 47.40 & 0.01 & 0.92 \\
\hline Pooled & 2224 & 328 & 55 ID : 9 D & 2193.12 & 358.88 & 3.01 & 0.08 \\
\hline \multicolumn{8}{|c|}{$\begin{array}{l}\text { Photo- } \\
\text { period } \\
\text { sensitive } \\
\text { background }\end{array}$} \\
\hline $\begin{array}{l}\mathrm{HA} 4 \times \mathrm{GL} \\
66\end{array}$ & 380 & 575 & $25 \mathrm{ID}: 39 \mathrm{D}$ & 373.05 & 581.95 & 0.21 & 0.64 \\
\hline
\end{tabular}


Table 5

The observed numbers of $\mathrm{F}_{3}$ families non- segregating for determinacy and indeterminacy and their goodness of fit to those expected in four crosses in photo-period insensitive and one cross in photo-period sensitive genetic backgrounds in dolichos bean

\begin{tabular}{|c|c|c|c|c|c|c|c|}
\hline \multirow[t]{2}{*}{ Crosses } & \multicolumn{2}{|c|}{$\begin{array}{l}\text { Observed number of } F_{3} \\
\text { families }\end{array}$} & \multirow{2}{*}{$\begin{array}{l}\text { Expected } \\
\text { proportion of } \\
\text { segregating (S) } \\
\text { and non- } \\
\text { segregating (NS) } \\
\text { in } \mathrm{F}_{3} \text { families }\end{array}$} & \multicolumn{2}{|c|}{$\begin{array}{l}\text { Expected number of } F_{3} \\
\text { families }\end{array}$} & \multirow{2}{*}{$\begin{array}{l}\text { Chi } \\
\text { square } \\
\text { statistic }\end{array}$} & \multirow[t]{2}{*}{ Probability } \\
\hline & $\begin{array}{l}\text { Non- } \\
\text { segregating } \\
\text { for growth } \\
\text { habit }\end{array}$ & $\begin{array}{l}\text { Segregating } \\
\text { for growth } \\
\text { habit }\end{array}$ & & $\begin{array}{l}\text { Non- } \\
\text { segregating } \\
\text { for growth } \\
\text { habit }\end{array}$ & $\begin{array}{l}\text { Segregating } \\
\text { for growth } \\
\text { habit }\end{array}$ & & \\
\hline \multicolumn{8}{|l|}{$\begin{array}{l}\text { Photo- } \\
\text { period } \\
\text { insensitive } \\
\text { background }\end{array}$} \\
\hline $\mathrm{HA} 4 \times \mathrm{HA} 5$ & 34 & 109 & $1 \mathrm{NS}: 3 \mathrm{~S}$ & 35.75 & 107.25 & 0.11 & 0.73 \\
\hline HA $5 \times$ HA 4 & 36 & 112 & $1 \mathrm{NS}: 3 \mathrm{~S}$ & 37.00 & 111.00 & 0.04 & 0.85 \\
\hline $\begin{array}{l}\mathrm{HA} 4 \times \mathrm{GL} \\
201\end{array}$ & 35 & 110 & $1 \mathrm{NS}: 3 \mathrm{~S}$ & 36.25 & 108.75 & 0.06 & 0.82 \\
\hline $\begin{array}{l}\text { GL } 201 \times \\
\text { HA } 4\end{array}$ & 34 & 108 & $1 \mathrm{NS}: 3 \mathrm{~S}$ & 35.50 & 106.50 & 0.08 & 0.77 \\
\hline Pooled & 139 & 439 & $1 \mathrm{NS}: 3 \mathrm{~S}$ & 144.50 & 433.50 & 0.28 & 0.60 \\
\hline \multicolumn{8}{|l|}{$\begin{array}{l}\text { Photo- } \\
\text { period } \\
\text { sensitive } \\
\text { background }\end{array}$} \\
\hline $\begin{array}{l}\mathrm{HA} 4 \times \mathrm{GL} \\
66\end{array}$ & 43 & 123 & $1 \mathrm{NS}: 3 \mathrm{~S}$ & 41.5 & 124.50 & 0.07 & 0.79 \\
\hline
\end{tabular}

\section{Discussion}

The mode of action of genes (though the number of genes remained same) controlling growth habit in dolichos bean differed with the degree of photoperiod sensitivity of the parents used to generate $F_{2}$ and $F_{3}$ populations. While growth habit is controlled by two genes that display duplicate dominant epistasis in crosses derived from PIS parents, it is controlled by two genes that display di-genic complementary epistasis in crosses derived from PS parents. Given that alleles controlling determinate growth habit and photoperiod insensitivity, and those controlling indeterminate growth habit and photoperiod sensitivity are tightly linked (with a recombination of 0.20 to 0.26 ) in coupling phase (Keerthi et al. 2014, 2016; Kaushal et al. 2019), it appears that in the presence of alleles controlling PIS, the two genes controlling growth habit mimic each other and either one or both of them in dominant status produce indeterminate growth habit and recessive alleles at both the loci are necessary to produce determinate growth habit. On the other hand, in the presence of alleles controlling PS, the two genes interact in complementary epistatic fashion and both the genes in dominant status are essential to produce indeterminate growth habit. Any other status at two loci will produce determinate growth habit. The variation in mode of action of genes controlling growth habit in relation to alleles controlling photoperiod sensitivity could be attributed to tight linkage between genes controlling the two traits (Keerthi et al. 2014, 2016; Kaushal et al. 2019) and we hypothesize that there exists interaction between them. The molecular/biochemical basis of the hypothesized interaction remains to be investigated. Based on the results of the present study, we have proposed most probable genotypes of parental, $F_{1}$ and $F_{2}$ populations (Table 6) using the notations suggested by Keerthi et al. (2014), Keerthi et al. (2016) and Kaushal et al. (2019). 
Table 6

The proposed genotypes of parents, and $\mathrm{F}_{1}$ and $\mathrm{F}_{2}$ generations under photo-period

\begin{tabular}{|c|c|c|c|c|c|c|c|}
\hline \multirow[t]{2}{*}{ Crosses } & \multicolumn{2}{|c|}{$\begin{array}{l}\text { Observed number of } \mathrm{F}_{3} \\
\text { families non-segregants for }\end{array}$} & \multirow{2}{*}{$\begin{array}{l}\text { Hypothesized } \\
\text { ratio of ID } \\
\text { and D } \\
\text { families }\end{array}$} & \multicolumn{2}{|c|}{$\begin{array}{l}\text { Expected number of } F_{3} \\
\text { families non-segregating for }\end{array}$} & \multirow[t]{2}{*}{$\begin{array}{l}\text { Chi } \\
\text { square } \\
\text { statistic }\end{array}$} & \multirow[t]{2}{*}{ Probability } \\
\hline & $\begin{array}{l}\text { Indeterminate } \\
\text { (ID) }\end{array}$ & $\begin{array}{l}\text { Determinate } \\
\text { (D) }\end{array}$ & & $\begin{array}{l}\text { Indeterminate } \\
\text { (ID) }\end{array}$ & $\begin{array}{l}\text { Determinate } \\
\text { (D) }\end{array}$ & & \\
\hline \multicolumn{8}{|c|}{$\begin{array}{l}\text { Photo- } \\
\text { period } \\
\text { insensitive } \\
\text { background }\end{array}$} \\
\hline$\underset{5}{\mathrm{HA}} 4 \times \mathrm{HA}$ & 25 & 09 & 3 ID : 1D & 25.5 & 8.50 & 0.04 & 0.84 \\
\hline $\begin{array}{l}\mathrm{HA} \\
4\end{array} \times \mathrm{HA}$ & 26 & 10 & 3 ID : 1D & 27.00 & 9.00 & 0.15 & 0.70 \\
\hline $\begin{array}{l}\mathrm{HA} 4 \times \mathrm{GL} \\
201\end{array}$ & 26 & 09 & 3 ID : 1D & 26.25 & 8.75 & 0.00 & 0.93 \\
\hline $\begin{array}{l}\text { GL } 201 \times \\
\text { HA } 4\end{array}$ & 26 & 08 & 3 ID : 1D & 25.50 & 8.50 & 0.04 & 0.84 \\
\hline Pooled & 103 & 36 & 3 ID : 1D & 104.25 & 34.75 & 0.06 & 0.80 \\
\hline \multicolumn{8}{|c|}{$\begin{array}{l}\text { Photo- } \\
\text { period } \\
\text { sensitive } \\
\text { background }\end{array}$} \\
\hline $\begin{array}{l}\mathrm{HA} 4 \times \mathrm{GL} \\
66\end{array}$ & 32 & 11 & 3 ID : 1D & 32.25 & 10.75 & 0.001 & 0.94 \\
\hline
\end{tabular}

The results of the present study, and those reported by researchers of our laboratory (Keerthi et al. 2014, Keerthi et al. 2016) and by others (Kaushal et al. 2019) clearly suggest that inheritance of growth habit is controlled by two major effect genes either in PS or PIS genetic backgrounds in dolichos bean. Our unpublished data indicate that determinate growth habit is a result of non-synonymous (sn) single nucleotide major effect mutations in dolichos bean homolog (candidate gene) ( $L P T F L 1$ ) of AtTFL 1, one of the major genes controlling growth habit in Arabidopsis. A major mutation in AtTFL 1 changes indeterminate to determinate growth habit in Arabidopsis (Wickland and Hanzawa 2015). In a latest study, Supriya et al. (2021) have reported that the splice site single nucleotide polymorphism (SNP) present at the end of the third exon of LPTFL 1 locus is responsible for transformation of short apical meristem into inflorescence in determinate genotype in dolichos bean. The splice site SNP leads to mutant LPTFL 1 locus that code for a non-functional protein due to absence of 14 amino-acids in determinate genotype. Gene prediction revealed that determinate and indeterminate genotypes differed in the length of third and fourth exons at LPTFL 1 locus (Supriya et al. 2021). Major mutations in homologs of other grain legumes such as soybean (GmTFL 1) (Tian et al. 2010), common bean (PVTFL 1) (Kwak et al. 2008, 2012; Repinski et al. 2012), pea (PSTFL 1) (Foucher et al. 2003), cowpea (VUTFL1) (Dhanasekar and Reddy 2015) and faba bean (VFTFL1) (Avila et al. 2007) are also reported to result in determinate growth habit from indeterminacy. Determinate growth habit in dolichos bean and in other grain legumes stands as a striking example for a major mutant trait becoming selectively advantageous in domesticated production environments (Koinange et al. 1996). These empirical results are adequately supported by evolutionary theoretical investigation which indicates that mutations with large effects provide opportunities for selection to enable crop's adaptation to contrasting environments (such as short- and long-days environments) leading to the appearance of distinctive adaptive traits (Dobzhansky et al. 1977) such as determinacy in grain legumes. 


\section{Implications For Breeding Dolichos Bean}

Considering that growth habit in dolichos bean is controlled by two major genes with determinacy being inherited by two recessive alleles, determinate plants needs to be selected in bi-parental crosses-derived early segregating generations (preferably in $\mathrm{F}_{3}$ ) to fix the alleles controlling determinacy), followed by selection for high grain yield potential in advanced generations. Raising as small as 230 plants is enough in $F_{2}$ populations derived from crosses involving parents in PS background as against 1600 plants in crosses involving parents with PIS background to recover a modest number (say 100) of determinate plants. We believe that this theoretical argument would prompt breeders to implement selection for determinate plants in a large number of crosses derived from PS background parents compared to the possibility of selection for such plants only in fewer crosses derived from PIS background parents. A precaution, however, needs to be exercised while implementing selection in segregating populations derived from PS background parents. Photoperiod sensitivity of determinate plants derived from PS background parents need to be examined by evaluating them in contrasting photoperiod environments to which cultivars are targeted, as cultivars with determinate growth habit in PIS background is desired. However, our experience (Keerthi et al. 2018 and others (Kim and Okubo 1995; Kim and Okubo 1996; Sultana et al. 2001) suggest that, in a few genetic backgrounds under short-days, it could be difficult to differentiate between determinate and indeterminate plants derived even from PIS parents-derived crosses in dolichos bean. Such situations warrants the use of validated tightly linked/candidate gene-based DNA for reliable identification of determinate plants in seedling stage itself even under short-day environments. As a first step towards developing such DNA markers, as already indicated in the previous section, we have now isolated and characterized $L P T F L 1$, the dolichos bean homolog (candidate gene) of Arabidopsis AtTFL1 gene (our unpublished data). We are now in the process of developing candidate gene-based markers. The use of such markers will help improve pace and efficiency of breeding dolichos bean by markerassisted selection for determinacy under high yielding background. Further, we believe that knowledge on the mode of action of genes/candidate genes controlling determinacy enable more effective use of secondary and tertiary gene pools in grain legumes (Krylova et al. 2020) including dolichos bean to broaden the genetic base of high yielding determinate cultivars.

\section{Declarations}

Acknowledgements The senior author gratefully acknowledges Council of Scientific and Industrial Research (CSIR), New Delhi, India for providing Junior Research Fellowship (JRF) vide No. 09/0271(11202)/2021-EMR-1 dated 01-07-2020 for pursuing PhD degree program at University of Agricultural Sciences, Bangalore, India.

Conflict of interest Author of this manuscript declare that we have no conflict of interest

Consent for publication All the authors have provided the consent for publication of this manuscript

Ethical approval This manuscript does not contain studies performed by any of the authors involving human or animals

Availability of data and material Not applicable

Code availability Not applicable

\section{References}

1. Avila CM, Atienza SG, Moreno MT, Torres AM (2007) Development of diagnostic marker for growth habit selection in faba bean (Vicia faba L.) breeding. Theor Appl Genet 115:1075-1082

2. Dhanasekar P, Reddy KS (2015) A novel mutation in TFL 1 homolog affecting determinacy in cowpea (Vigna unguiculata). Mol Genet Genomics 290:53-65

3. Dobzhansky T, Ayala FJ, Stebbins GL, Valentine JW (1977) Evolution. Freeman, San Franscisco

Page 10/12 
4. Foucher F, Morin J, Courtiade J, Cadioux S, Ellis N, Banfield MJ, Rameau (2003) Determinate and late flowering are two terminal flower/centroradialis homologs that control two distinct phases of flowering initiation and development in pea. Plant Cell 15(11):2742-2754

5. Harland SC (1920) Inheritance in Dolichos lablab L. Part I. J Genet 10:219-226

6. Huyghe C (1998) Genetics and genetic modifications of plant architecture in grain legumes: a review. Agronomie 18:383-411

7. Kato S, Sayama T, Taguchi-Shiobara F, Kikuchi A, Ishimoto M, Cober E (2019) Effect of change from determinate to a semi-determinate growth habit on the yield and lodging resistance of soybeans in the north-east region of Japan. Breed Sci 69(1):151-159

8. Kaushal M, Bhushan K, Dipesh B, Vinita RR, Bhuriya A (2019) Inheritance patterns of photoperiod responsive flowering, growth habit and flower colour in Indian bean [Lablab purpureus (L.) Sweet]. Electronic J Plant Breeding 10(1):297-302

9. Keerthi CM, Ramesh S, Byregowda M, Mohan Rao A, Reena GAM (2018) Photo-thermal effects on time to flowering in dolichos bean (Lablab purpureus (L.) Sweet) var. lignosus. Curr Sci 115(7):1320-1327

10. Keerthi CM, Ramesh S, Byregowda M, Rao AM, Rajendra Prasad BS, Vaijayanthi PV (2014) Genetics of growth habit and photoperiodic response to flowering time in dolichos bean (Lablab purpureus (L.) Sweet). J Genet 93:203-206

11. Keerthi CM, Ramesh S, Byregowda M, Rao AM, Rajendra Prasad BS, Vaijayanthi PV (2016) Further evidence for the genetic basis of qualitative traits and their linkage relationships in dolichos bean (Lablab purpureus (L.) Sweet). J Genet 95(1):89-98

12. Kim SE, Okubo H (1995) Control of growth habit by grafting between determinate indeterminate lablab bean (Lablab purpureus) plants. J Fac Agric Kyushu Univ 39:229-234

13. Kim SE, Okubo H (1996) Control of growth habit in determinate lablab bean (Lablab purpureus) by temperature and photoperiod. Sci Hort 61(3-4):147-155

14. Kim SE, Okubo H, Kodama Y (1992) Growth response of dwarf Lablab bean [Lablab purpureus (L.) Sweet] to sowing date and photoperiod. J Japanese Society Hort Sci 61(3):589-594

15. Koinange EMK, Singh SP, Gepts P (1996) Genetic control of the domestication syndrome in common bean. Crop Sci 36:1037-1045

16. Krylova EA, Khlestkina EK, Burlyaeva MO, Vishnyakova MA (2020) Determinate growth habit of grain legumes: role in domestication and selection, genetic control. Ecological Genetics 18(1):43-58. https://doi.org/10.17816/ecogen16141

17. Kwak M, Toro O, Debouck DG, Gepts P (2012) Multiple origins of the determinate growth habit in domesticated common bean (Phaseolus vulgaris). Ann Bot 110(8):1573-1580. https://doi.org/10.1093/aob/mcs207

18. Kwak M, Velasco D, Gepts $P$ (2008) Mapping homologous sequences for determinacy and photoperiod sensitivity in common bean (Phaseolus vulgaris). J Heredity 99(3):283-291. https://doi.org/10.1093/jhered/esn005

19. Laxmi K, Vaijayanthi PV, Keerthi CM, Shivakumar MS, Ramesh S, Rao AM (2016) Genotype-dependent photoperiodinduced sensitivity to flowering time in dolichos bean (Lablab purpureus (L.) Sweet var. lignosus). Bangladesh J Bot 45(3):471-476

20. Ramesh S, Byregowda M (2016) Dolichos bean (Lablab purpureus (L.) Sweet var. lignosus) genetics and breeding: present status and future prospects. Mysore J Agric Sci 50(3):481-500

21. Ramesh S, Byregowda M, Keerthi CM, Reena M, Ramappa HK, Rajendra Prasad BS (2018) ha 10-2 (HA5); Promising high yielding advanced breeding line for use in commercial cultivation of dolichos bean (Lablab purpureus (L.) Sweet). Mysore J Agric Sci 52(1):1-5

22. Repinski SL, Kwak M, Gepts $P$ (2012) The common bean growth habit gene PvTFL 1y is a functional homolog of Arabidopsis TFL 1. Theor Appl Genet 124(8):1539-1547. https://doi.org/10.1007/s00122-012-1808-8

23. Sultana N, Ozaki Y, Okubo H (2001) Early identification of determinate growth habit in lablab bean (Lablab purpureus (L.) Sweet). J Fac Agric Kyushu Univ 46(1):31-38

Page $11 / 12$ 
24. Supriya K, Apexa P, Kaushal M, Vipukumar P, Bhushan K, Gopal V, Ritesh P (2021) Allelic characterization and protein structure analysis reveals the involvement of splice site mutation for growth habit differences in Lablab purpureus (L.) Sweet. J Genetic Engg Biotech. doi.org/10.1186/s43141-021-00136s

25. Tian Z, Wang X, Lee R, Li Y, Specht E, Nelson L, McClean E, Qiu L, Ma J (2010) Artificial selection for determinate growth habit in soybean. Proc. Nat. Aca. Sci USA 107 (19): 8563-8568

26. Vinita R, Arpit B, Dipendra A, Vipukumar P, Kaushal M, Bhushan K, Gopal V, Ritesh P (2019) Molecular tagging of photoperiod responsive flowering in Indian bean [Lablab purpureus (L.) Sweet].Indian J Genet79 (1): Suppl 264-269

27. Wickland DP, Hanzawa Y (2015) The FLOWERING LOCUS T/TERMINAL FLOWER 1 gene family: functional evolution and molecular mechanisms. Mol Plant 8(7):983-997. https://doi.org/10.1016/j.molp.2015.01.007 